\title{
Organophosphate insecticide susceptible test and transovarial transmission detection of dengue virus on Aedes aegypti in Kendari
}

\author{
Muhaimin Saranani $^{*}$, Sitti Rahmah Umniyati ${ }^{2}$, Tri Baskoro Tunggul Satoto ${ }^{2}$ \\ ${ }^{1}$ Polytechnic of Kendari, Ministry of Health in Kendari, ${ }^{2}$ Department of Parasitology, Faculty of \\ Medicine, Universitas Gadjah Mada, Yogyakarta, Indonesia
}

\begin{abstract}
Dengue Fever (DF) is a disease caused by the dengue virus that transmitted by Aedes aegypti (Ae. Aegypti) and Ae. albopictus. Dengue fever is now one of the most important public health problems in Indonesia. Vector control using insecticides is the most important strategy to control the DF. Massal fogging and selective abatisation have implementedd intensively to control Ae. aegypti. However after its a long time implementation, mosquitoes resistance and transovarial transmission have been reported. The aim of the study was to evaluate the susceptibility status of Ae. aegypti to organophosphate and its ability to transovarial transmit degue virus in Kendari City, South East Sulawesi. This was a observational study using cross-sectional design conducted in high endemic areas (Kadia Village) and low endemic areas (Kambu Village). Susceptibility status of $A$ e. aegypti larvae from F1's egg generation was evaluated by biochemic assay, whereas the transovarial transmission of dengue virus of adult female Ae. aegypti was evaluated by immunohistochemistry method using head squash preparation. The results showed that the $A e$. aegypti larvae resistant was higher in high endemic areas (Kadia Village) $(83.33 \%$ ) than in low endemica areas (Kambu Village) $(60.00 \%)$. In addition, transovarial transmission index (TTI) of Ae. aegypti dengue virus in the high endemic areas $(26 \%)$ was significantly higher than in the low endemic areas $(12 \%)(\mathrm{p}<0.05)$. In conclusion, the Ae. aegypti larvae resitance to organophosphate as well as the TTI in high endemic areas is higher than in low endemic area in Kendari, Sout East Sulawesi.
\end{abstract}

\section{ABSTRAK}

Demam berdarah dengue (DBD) adalah suatu penyakit yang disebabkan oleh virus dengue yang ditularkan oleh nyamuk Aedes aegypti (Ae. Aegypti) dan Ae. albopictus. Demam berdarah dengue saat ini menjadi salah satu masalah kesehatan masyarakat yang penting di Indonesia. Pengendalian vektor menggunakan insektisida merupakan strategi penting dalam mengendalikan DBD. Program fogging masal dan abatisasi selektif telah dijalankan secara intensif untuk mengendalikan $A e$. aegypti. Namun demikian, setelah lama dilaksanakan, terjadinya resitensi nyamuk dan transmisi transovari telah dilaporkan. Penelitian ini bertujuan untuk mengkaji status kerentanan Ae. aegypto terhadap organofosfat dan kemampuan transmisi transovari virus dengue di Kota Kendari, Sulawesi Tenggara. Penelitian ini merupakan penelitian observasional menggunakan rancangan crosssectional yang dilakukan di daerah dengan endemisitas tinggi (Desa Kadia) dan daerah endemisitas rendah (Desa Kambu). Status kerentanan Ae. aegypti larva dari telur generasi pertama (F1) ditetapkan dengan metode biokimia sedangkan transmisi transovari virus dengue pada nyamuk dewasa betina Ae. aegypti dievalusi dengan metode imunohistokemia menggunakan sediaan head squash. Hasil penelitian menunjukkan bahwa larva Ae. aegypti yang resisten lebih tinggi di daerah dengan endemisitas tinggi (Desa Kadia) $(83,33 \%)$ dibandingkan di daerah dengan endemisitas rendah (Desa Kambu) $(60,00 \%)$. Selain itu, indeks transmisi transovari (ITT) virus

\footnotetext{
* corresponding author: muhaimin.saranani@yahoo.com
} 
dengue Ae. aegypti di daerah dengan endemisitas tinggi (26\%) lebih tinggi secara nyata dibandingkan dengan di daerah dengan endemisitas rendah $(12 \%)(p<0.05)$. Dapat disimpulkan, larva $A$ e. aegypti yang resisten organofosfat dan ITT di daerah dengan endemisitas tinggi lebih tinggi dari pada daerah dengan endemisitas rendah di Kendari, Sulawesi Tenggara.

Keywords: Ae. aegypti - resistance status - organophosphat - dengue virus - transovarial transmission

\section{INTRODUCTION}

Dengue fever is a mosquito-borne disease caused by the dengue virus that transmitted by Aedes aegypti (Ae. Aegypti) as the main vector and Ae. albopictus as a potential vector. ${ }^{1}$ Dengue fever is now one of the most important public health problems in tropical developing countries. ${ }^{2}$ It is estimated that between 50 to 100 million people are infected by dengue virus causing 250.000 to $500.000 \mathrm{DF}$ and nearly 22.000 deaths annually especially in children. ${ }^{3}$ In Indonesia in 2006, 113.640 cases of DF and 1.184 deaths was reported in 2006. In 2007, these cases increased to be 139.624 cases however the number of deaths decreased to be 738 deaths. $^{4}$

In South East Sulawesi, the incidence of DF is relatively high distributed in 12 districts or cities and suffered by all age groups. In 2009, 772 cases of DF was reported. In 2010, these cases increased to be 1.251 cases and in 2011 decreased to be 3010 cases. Kendari City is one of districts in South East Sulawesi where the dengue cases is relatively higher compare to other districts. The DF cases and deaths due to DF have been reported annually since $2005 .{ }^{5}$

Dengue virus comprises four distinct serotypes named DEN-1, DEN-2, DEN-3 and DEN-4 which belong to the genus Flavivirus in the family Flaviviridae. ${ }^{6}$ Dengue virus in Ae. aegypti can be transmitted horizontally as well as vertically through transovarial transmission. The transovarial transmission of dengue virus is a crucial etiological phenomenon responsible for persistence of virus during inter-epidemic periods. ${ }^{7,8}$ During the transovarial transmission, the virus can be maintained in nature of mosquitoes and can replicate in potentially vulnerable tissue of mosquito ovaries and embryos without deleterious effects. ${ }^{9}$

Currently, DF prevention still mostly depends on vector control due to lack effective treatment for DF and no vaccine for prevention. Control of Ae. aegypty is the most important measure in DF prevention because these mosquitoes tend to act as a reservoir or amplifier host for dengue viruses. ${ }^{10}$ Organophosphate insecticides play an important role for the mosquitoes control. It has been utilized intensively as the main strategy to control mosquitoes through massal fogging and selective abatisation. ${ }^{11}$ However after a long time use of the organophosphate insecticides, masquitoes resistance to organophosphate have been reported worldwide. ${ }^{12-14}$ Moreover, persistance of dengue virus in the successive generations of mosquitoes infected through transovarial transmissions has been reported. ${ }^{8,9}$

This study was conducted to investigate the susceptibility status of Ae. aegypti to organophosphate insecticides and its ability to transmit dengue virus by transovarial transmission in Kendari City, South East Sulawesi.

\section{MATERIALS AND METHODS}

\section{Research design}

This was a observational study using crosssectional design conducted in high endemic areas (Kadia Village) and low endemic areas 
(Kambu Village) in Kendari District. The study was carried out from November 2011 to April 2012. Protocol of the study was approved by the Medical and Health Research Ethics Committee, Faculty of Medicine, Universitas Gadjah Mada, Yogyakarta.

\section{Mosquito collection}

Aedes aegypti mosquito was sampled as eggs. Aedes aegypti's eggs were obtained randomly from different research locations using ovitraps. Ovitraps were placed in the potential mosquito breeding in or out site of the house weekly for about one month. The eggs were then collected and colonized to their F1 generation in Laboratory of Parasitology, Faculty of Medicine, Universitas Gadjah Mada. Two hundred and thirteen larvae from mosquito eggs hathced were used for susceptibility status test of Ae aegypti to malation and 246 adult mosquitoes were used for transovarial transmission of dengue virus detection.

\section{Susceptibility status assay}

Susceptibility status of larvae to organophosphate insecticide was assessed using biochemical assay for non specific esterase activities. Sixty third or fouth instars larvae from low or high endemic areas were homogenized in $500 \mu \mathrm{L}$ phosphate buffer solution. Using micropipette, $50 \mu \mathrm{L}$ homogenate was transferred to each well of a microplate. Fifty $\mu \mathrm{L}$ subtrate solution containing $\alpha$-napthyl acetate in acetone and PBS was added to each well of the microplate and left for one minute. Fifty $\mu \mathrm{L}$ coupling reagent was added into each well of the microplate and incubated for 10 minutes. Change of colour reaction from red to blue took place immediately. The reaction was stopped by adding of $50 \mu \mathrm{L}$ acetic acid into each well of the microplate. The presence and level of esterase quantitatively were indicated by the colour intensity which is also directly proportional to the esterase activity. The esterase activity was scored visually as follow 0 for colorless; 1 for light blue; 2 for greenish blue and 3 for dark blue. Furthermore, the susceptibility status of larvae was determined semiquantitatively based on the the visual score according to Lee. ${ }^{15}$ The larvae was considered to be sensitive (SS) if the esterase activity score was $<2.0$ (colorless or greenish yellow); to be tolerant (RS) if those score was from 2.0 to 2.5 (light blue greensih blue); to be resistant (RR) if those score was from 2.6 to 3.0 (dark blue). The esterase activity was also determined quantitatively based on the absorbance value after read using an ELISA reader at a $\lambda$ of 450 $\mathrm{nm}$. Furthermore, the susceptibility status of larvae was determined quantitatively based on the absorbance value according to Soebono. ${ }^{16}$ The larvae was considered to be resistant if the absorbance value was $\geq$ means absorbance value of sensitive larvae \pm 2 SD.

\section{Detection of dengue virus}

The dengue virus present in the tissues of mosquito was determined by monoclonal dengue antibodies using the immunohistochemistry streptavidin-biotin-peroxidase complex (ISBPC). After fixation in cold methanol at $-20^{\circ} \mathrm{C}$ for $3-5$ minutes, the head squash preparation was washed in aquadest and then PBS (phosphate buffer saline). The specimen was then incubated with peroxidase blocking solution at room temperature for 10 minutes and washed in PBS to stop endogenous peroxidase activity. The specimen was then incubated with serum blocking solution (back ground sniper) at room temperature for 10 minutes to suppress non-specific binding of subsequent reagents, followed by incubation with primary antibody (monoclonal antibody anti DSSE10 (1:5) at room temperature for 60 
minutes. The specimen was then washed in PBS and sequentially incubated with biotin-labelled secondary antibody (Trekkie Universal Link) at room temperature for 20 minutes. The specimen was then washed in PBS and incubated with peroxidase-streptavidin conjugate to HRP (Trek Avidin-HRP) at room temperature for 10 minutes. The specimen was washed in PBS and the presence of peroxidase was visualized by incubation in substrate-chromogen solution (Betazoid DAB Chromogen) for 5-10 minutes and counterstained with Mayer's hematoxyline solution. Dengue antigen was detected under light microscope at 40, 100, 400 and $1000 \mathrm{x}$ magnification. Positive antigen was detected as brownish color in the cytoplasm of infected cells in most of mosquito brain tissue while negative result was detected as blue or sallowness color in most of brain tissue. Unstored infected mosquitoes specimen was used as positive control, and un-infected mosquitoes specimen was used as negative control. Transovarial transmission index (TTI) was then calculated.

\section{Statistical analysis}

The chi-square test was performed to compare the susceptibility status of larvae as well as transovarial transmission index of dengue virus between low and high endemic areas. A p value less than 0.05 was considered as statistically significant. Statistical analysis was performed with computer software program.

\section{RESULTS}

\section{Susceptibility status of Ae. aegypti to organophosphate}

The susceptibility status of Ae. aegypti larvae to organophosphate insecticide in high (Kadia Village) and low (Kambu Village) endemic area after biochemical assay using semiquantitative (visual) analysis was presented in FIGURE 1. The higher Ae. aegypti larvae resistant was observed in high endemic area i.e. Kadia Village (83.33\%) compare to low endemic area i.e. Kambu Village $(60.00 \%)$. Moreover, no sensitive larvae were observed in high endemic area.

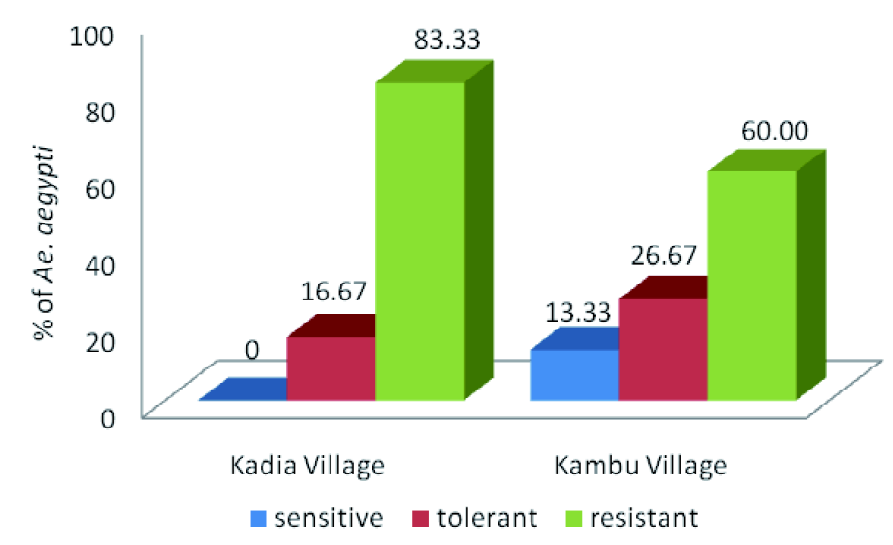

FIGURE 1. Susceptibility status of Ae. aegypti larvae to organophosphate insecticides after biochemic assay using semiquantitative (visual) analysis 
FIGURE 2 present the susceptibility status of Ae. aegypti larvae to organophosphate insecticide in high (Kadia Village) and low (Kambu Village) endemic area after biochemical assay using quantitative analysis. The higher $A e$. aegypti larvae resistant was observed in high endemic areas i.e. Kadia Village (100.00\%) compare to low endemic areas i.e. Kambu Village (53.33\%). All of Ae. aegypti larvae collected from high endemic areas were resistant.

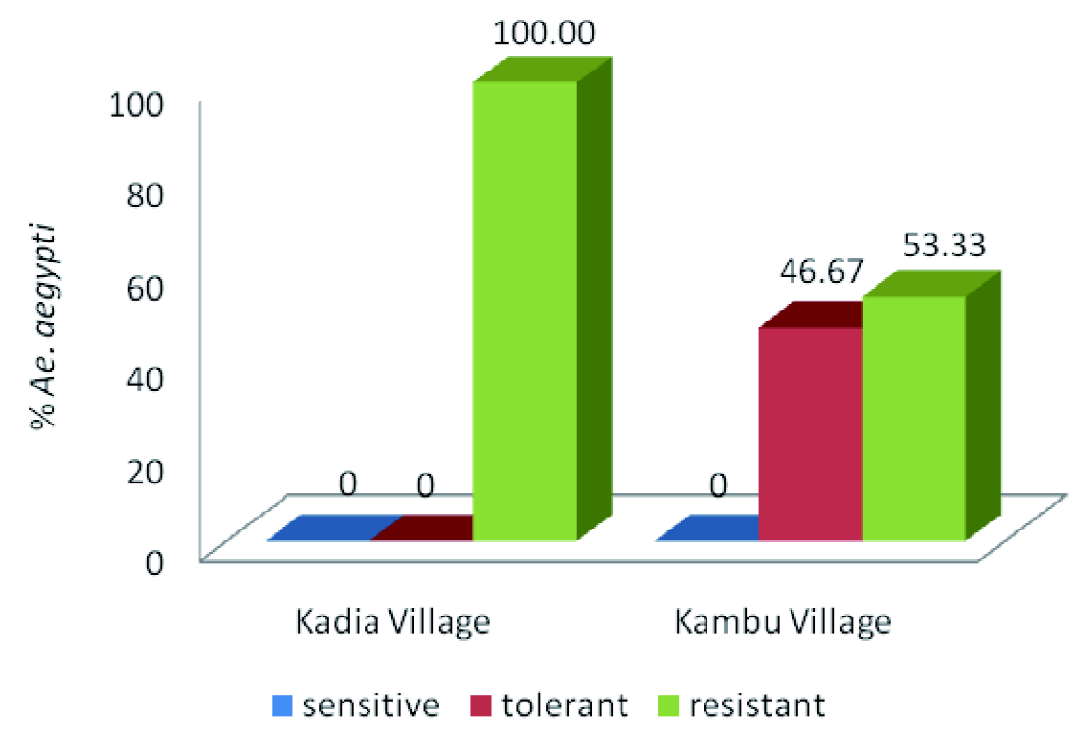

FIGURE 2. Susceptibility status of Ae. aegypti larvae to organophosphate insecticides after biochemic assay using quantitative analysis

\section{Transovarial transmission index of dengue virus on Ae. aegypti}

FIGURE 3 shows a dengue-positive $A e$. aegypti head squash with $400 \mathrm{x}$ magnification, where the brownish precipitation (white arrows) indicates the location of dengue antigen in the infected mosquito while blue or pale color indicates no dengue antigen observed. Transovarial Transmission Index of Ae. aegypti dengue virus in the high endemic areas $(26 \%)$ was significantly higher than in the low endemic areas $(12 \%)(\mathrm{p}<0.05)$. 


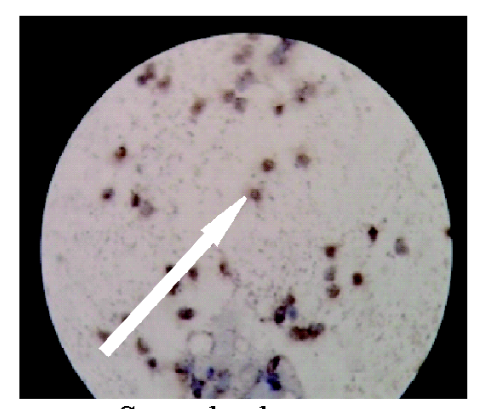

Sample: brown (virus positive)

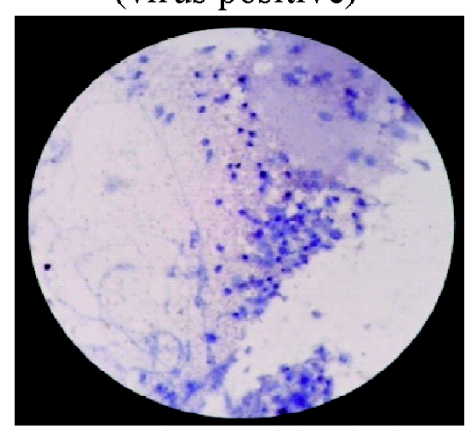

Control IHC: blue/pale

(virus negative)

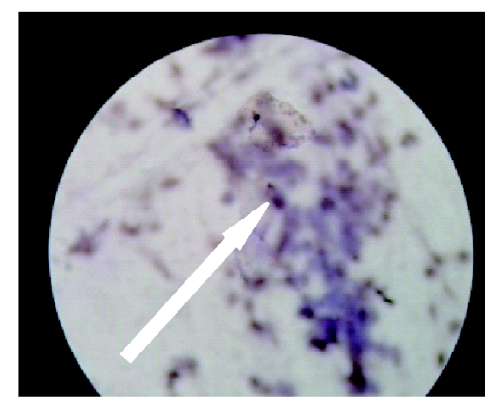

Positive control: brown (virus positive)

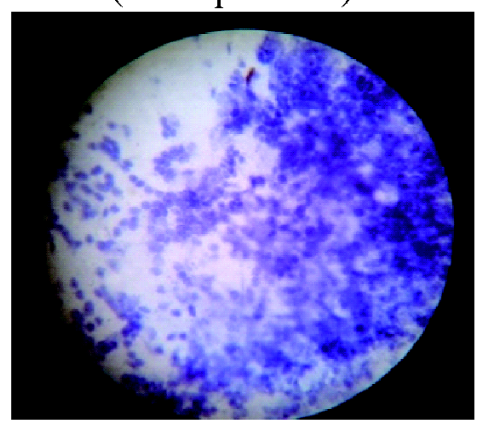

Negative control: blue/pale (virus negative)

FIGURE 3. Aedes aegypti head squash preparation with streptavidinbiotin peroxidase complex staining with $400 \mathrm{x}$ magnification. Positive dengue virus antigen was indicated as brownish color (white arrows) while negative result was detected as blue or pale

TABLE 1. The TTI of dengue virus in Ae. aegypti collected from high endemic areas (Kadia Village) and low endemic areas (Kambu Village) in Kendari

\begin{tabular}{lcccc}
\hline \multirow{2}{*}{ No } & Sampling location & \multicolumn{3}{c}{ Number } \\
\cline { 3 - 5 } & & Sample & Positive & TTI (\%) \\
\hline 1. & Kadia Village (high endemic area) & 123 & 32 & 26 \\
2. & Kambu Village (low endemic area) & 123 & 15 & 12 \\
\hline & Total & 246 & 47 & 38 \\
\hline
\end{tabular}

\section{DISCUSSION}

\section{Susceptibility status of Ae. aegypti to organophosphate}

The susceptibility status of Ae. aegypti larvae under biochemic assay showed a significantly differences between high and low endemic areas $(\mathrm{p}<0.05)$. Aedes aegypti larvae in the high endemic areas had higher resistance to organophosphate insecticides than in low endemic areas. The result of this study is in accordance with study conducted by Sitorus ${ }^{17}$ in Sukarawe, Palembang which showed the decrease of Ae. aegypti susceptibility to malation and temephos.

Gene differences of Ae. aegypti population in high and low endemic areas may contribute 
to differences in susceptibility status of $A e$. aegypti larvae. It led to the different activities of non specific esterase enzymes on each individual of Ae. aegypti. In molecular level, the increase in esterase enzymes of resistant strains are caused by genes amplification (esterase á-2 dan esterase â-2) encoding esterase enzymes and subsequently enhanced the gene expression. ${ }^{18}$ Enzyme growth can also occur as a result of esterase which is selectively pressed from the pitetroid insecticide use as household insecticides. ${ }^{19}$ Gene complexity also contributes to the decrease of Ae. aegypti susceptibility status, meaning that the more genes controlling of resistancy of the insects to insecticides. More many genes involved in the resistancy process of an insecticide, the incidence of resistance will occur slowly and otherwise if not many genes involved. ${ }^{20}$

This study showed that Ae. aegypti larvae in both high and low endemic areas in Kendari, South East Sulawesi were not sensitive again to organphosphate insecticide (FIGURE 2). The Department of Health in Kendari reported that organophosphate insecticide (temephose) as larvicide has been used since 11 years ago. However, the overuse of this larvicide has been observed due to the lack of direct control from Department of Health especially Primary Health Services in Kendari. Temephos can be sold freely in many drug store in Kendari. This condition is actually ideal since the people do not depend on the government's abatisation program. Nevertheless, it can also bring a negative effect to emergence of Ae. aegypti larvae resistance when its use is not appropriate. Temephos is often used in sub dose by community in order to reduce the odor of water containing temephos.

Lima et al. ${ }^{21}$ reported that the continuous usage of insecticides may cause negative impact and the emergence of resistant insects to the insecticide. Moreover, the susceptibility status of Ae. aegypti decreases when the insecticide is continuously used in a broad scale, long periods, and high frequency. ${ }^{22}$ The irrational use of larvicide like temephos can cause the resistance of insects. ${ }^{23}$

Malathion is reported remain effective against Ae. aegypti in Kadia and Kambu Villages, Kendari, although it has been used since 14 years ago. It is because malathion is not used continously in these areas. ${ }^{6}$ Therefore, malathion can be recommended against $A e$. aegypti restant in Kadia and Kambu Villages. However, the appropriate use of malathion should be considered in order to avoid the $A e$. aegypti resistance growth.

\section{Transovarial transmission index of dengue virus on Ae. aegypti}

In this study, the TTI of Ae. aegypti dengue virus in the high endemic areas $(26 \%)$ was significantly higher than in the low endemic areas $(12 \%)(\mathrm{p}<0.05)$. The correlation of TTI between the high and low endemic areas is related to high number of population, the population mobility, as well as community's low awareness to the Ae. aegypti's nest prevention (PSN), which makes dengue virus spread easier. Number of population in endemic areas also plays a role in transmission of dengue virus. If the number of population increases, dengue virus infection will occur easier than in the areas with less population, as more populations support the high frequency contact with Ae. aegypti vectors due to its antropofilic and multiple bites. ${ }^{24}$

Demographic and society changes such as population growth, urbanization, and modern transport also play an important role in the improvement of many incidents and activities, including the spread of dengue virus, due to geographical circumstances, which can extend the distribution of viruses and increase the frequency of the epidemic. ${ }^{25}$ 
Dengue virus potentially increases transovarial DF or contributes to frequent incidence of endemic areas in DHF'cases. ${ }^{26} \mathrm{In}$ addition, some factors that affect the transmission of dengue virus infection are human, Ae. aegypti and vectors as mediator between $A e$. aegypti and virus. ${ }^{27}$

\section{CONCLUSION}

The Ae. aegypti larvae resitance to organophosphate insecticide in high endemic areas (Kadia Village) in Kendari is significantly higher than in low endemic areas (Kambu Village). Resistant Ae. aegypti to temephos is observed in these areas, however malathion is still effective against Ae. aegypti. Transovarial transmission index of dengue virus in $A e$. aegypti is significantly higher in high endemic areas (Kadia Village) than in low endemic areas (Kambu Village).

A guidance for community about the appropriate usage of temephos as well as discovering of alternatives insecticide to replace temephos are needed. Fogging program should be conducted for a minimum of 2 cycle focuses on DHF cases point. Several factors causing resistance of Ae. aegypti and areas mapping of resistency to organophosphate need to be further examined.

\section{ACKNOWLEDGEMENTS}

The authors would like to thank the Head of Department of Health in Kendari, and the Director of Health Polytechnic of Kendari, Ministry of Health for their support during this study.

\section{REFERENCES}

1. Malvige GN, Fernando S, Seneviratne SL. Dengue viral in infection. Postgrad Med J 2004; 80: 588601.

2. Gubler DJ. Epidemic dengue/dengue hemorrhagic fever as a public health, social and economic problem in the 21 st century. Trends Microbiol 2002; 10(2):100-3.

3. WHO. Dengue and dengue hemorrhagic fever: WHO fact sheet 117. Geneva: World Health Organization, 2002.

4. Ginanjar. Demam berdarah, a survival quide, $1^{\text {st }}$ eds. PT Benteng Pustaka: Yogyakarta.

5. WHO. Prevention control of dengue and dengue haemorrhagic fever. WHO regional Publication SAERO, 29: 361-2.

6. Dinkes Kota Kendari. Laporan Kasus DBD Kota Kendari Tahun 2006 s/d 2011. Kendari: Dinkes Kota Kendari, 2011.

7. Lee HL, Rohani A. Transovarial transmission of dengue virus in Aedes aegypti and Aedes albopictus in relation to dengue outbreak in an urban area in Malaysia. Dengue Bull 2005; 29:10611.

8. Joshi V, Mourya DT, Sharma RC. Persistence of dengue- 3 virus through transovarial transmission passage in successive generations of Aedes aegypti mosquitoes. Am J Trop Med Hyg 2002;67: 158-61.

9. Borucki MK, Kempf BJ, Blitvich BJ, Blair CD, Beaty BJ. La Crosse virus: replication in vertebrate and invertebrate hosts. Microbes Infect 2002;4:341-50.

10. Hartanti MD, Suryani, Tirtadjaja IG. Dengue virus transovarial transmission by Aedes aegypti. Universa Med 2010; 29(2): 65-70.

11. Sukowati S. Masalah demam berdarah dengue dan pengendaliannya di Indonesia. Buletin Jendela Epidemiologi 2010; 2: 26-30.

12. Rodriguez MM, Bisset J, de Fernadez DM, Lauzan L, Soca A. Detection of insecticide resistance in Aedes aegypti (Diptera: Culicidae) from Cuba and Venezuela. J Med Entomol 2001; 38(5):623-8.

13. Lidia K, Setyaningrum ELS. Deteksi dini resistensi nyamuk Aedes albopictus terhadap insektisida organofosfat di daerah endemis demam berdarah dengue di Palu (Sulawesi Tengah). MKM 2008; 3(2):105-10.

14. Rawlins SC. Spatial distribution of insecticide resistance in Caribbean populations of Aedes aegypti and its significance. Pan Am J Pub Health 1998; 4(4): 243-51.

15. Lee HL. Esterase activity and temephos susceptibility in Aedes aegypti larvae. Mosquito Borne Dis Bull 1991; 8: 91-4. 
16. Soebono H. Infeksi subklinis Mycrobacterium leprae dan hubungannya dengan faktor-faktor risiko di Indonesia. Kajian seroepidemiologi dan imonologik [Disertasi]. Yogyakarta: Universitas Gadjah Mada, 1996.

17. Sitorus H. Deteksi resistensi Aedes aegypti dan Aedes albopictus terhadap malation dan temefos serta pemetaan kerawanan infeksi DBD di Kecamatan Sukarame Kota Palembang [Tesis]. Yogyakarta: Progran Study Ilmu Kedokteran Tropis, Universitas Gadjah Mada, 2008.

18. Widiarti. Uji mikroplat aktivitas enzim esterase untuk mendeteksi resistensi Anopheles aconitus terhadap insektisida malation. J Kedok YARSI 2005;13 (1): 1-10.

19. Widiarti, Boewono DT, Widyastuti U, Mujiono, Lasmiati. Deteksi virus dengue pada induk dan progeny vektor demam berdarah Aedes aegypti di beberapa daerah endemis di Jawa Tengah. Dalam Seminar Sehari Strategi Pengendalian Vektor dan Reservoir Penyakit pada Kedaruratan Bencana Alam di Era Desentralisasi. Salatiga: 20 September 2006.

20. Soedarto. Entomologi kedokteran. Jilid I. Jakarta: EGC, 1992.

21. Lima JBP, Da-Cunha MP, Junior RCS, Galardo AKR, Soares SS, Braga IA, et al. Resistance of Aedes aegypti to organophosphates in several municipalities in the state of Rio de Janeiro and Espirito Santo, Brazil. Am J Trop Med Hyg 2003; 68(3):329-33.
22. Macoris MLG, Andrighetti MTM, Takakku L, Glasser CM, Garbeloto VC, Bracco JE. Resistence of Aedes aegypti from the state of sao paulo, Brasil, to organophosphate insecticides. Mem Inst Oswaldo Cruz. Rio de Janeiro 2003; 98(5):703-8.

23. Jirankanjanakit N, Saengtharatip S, Rongnoparut P, Duchon S, Bellec C, Yoksan S. Trend of temephos resistance in Aedes (Stegomyia) mosquitoes in Thailand during 2003-2005. Environ Entomol 2007; 36:506-11.

24. Sutaryo. Dengue. Yogyakarta: Medika FK UGM, 2004.

25. Gubler DJ. The global emergence/resurgence of arboviral disease as public health problems. Arch Med Res 2002;33:330-42.

26. Thavara U, Siriyasatien P, Tawatsin A, Asavadachanukorn P, Anantapreecha S, Wongwanich. Double infection of heteroserotypes of dengue viruses in field populations of Aedes aegypti and Aedes albopictus (Diptera:Culicidae) and serological features of dengue viruses found in patients in southern Thailand. J Trop Med 2006; 37:468-76.

27. Mardihusodo SJ, Satoto TBT, Mulyaningsih B, Umniyati SR, Ernaningsih. Bukti adanya penularan virus dengue secara transovarial pada nyamuk Aedes aegypti di Kota Yogyakarta. Simposium Nasional Aspek Biologi Molekuler: Patogenesis, Manajemen dan Pencegahan KLB. Yogyakarta: Pusat Studi Bioteknologi UGM, 2007. 